\title{
Effect of air-drying of Acacia cyanophylla Lindl. leaves on intake and digestion by sheep
}

\author{
H Abdouli 1, H Ben Salem 2, A Nefzaoui 2, H Ferchichi 2, Lamia Ben Salem ${ }^{3}$ \\ 'Ecole Supérieure d'Agriculture de Mateur, 7049 Mateur; 2INRAT, Laboratoire de Nutrition Animale, rue Hédi \\ Karray, 2049 Ariana; 'Office de l'Elevage et des Pâturages, rue Alain Savary, 1002 Tunis, Tunisia
}

Leaves of Acacia cyanophylla are quite rich in proteins $(13 \%)$ and in tannins ( 4 to $7 \%$ DM). The tannins, which are mostly of condensed type, seem to form insoluble complexes with the proteins and reduce their availability to ruminal microbes and therefore decrease the leaves nutritive value and palatability. The latter seems to be improved when leaves are air-dried. The aim of the present study was to compare fresh to air-dried leaves for their intake, digestibility and rumen fermentation parameters.

Four rumen cannulated and four non cannulated mature sheep of "Queue Fine de l'Ouest" breed were used in a cross-over design $(4 \times 2)$ to test the two diets : $600 \mathrm{~g}$ of alfalfa hay $+30 \mathrm{~g}$ of mineral mixture + either freshly cut acacia leaves ad libitum (D1), or 1 week air-dried acacia leaves ad libitum (D2). Each of the experimental periods lasted for 25 days. Animals were adapted to the diets for the first 15 days and intake, digestibility and rumen

Diets

D1

Acacia digestibility $(\%)^{*}$

$\mathrm{OM}$

52.7

$\mathrm{CP}$

23.4

CF

37.0

Fermentation parameters

$\mathrm{pH}$

6.76

$\mathrm{N}-\mathrm{NH} 3, \mathrm{mg} / 100 \mathrm{ml}$

Total VFA, mmol//

Acetate, \% total

Propionate, \% total

Butyrate, \% total

* calculated by difference
6.30

67.7

74.6

17.1

8.2 fermentation parameters were measured for the remaining 10 days.

Air-drying acacia leaves increased their dry matter (DM) content from 49.8 to $86.2 \%$ but did not affect $C P$ and tended to lower CF, ADF and $A D L$ contents. Acacia mean DM intake increased $(P<0.05)$ from 861 to $935 \mathrm{~g} / \mathrm{d}(52.6$ to $56.5 \mathrm{~g} / \mathrm{kg} \mathrm{LW0.75)}$. The intake pattern showed an interday variation which suggested a tannins cumulative effect. Organic matter digestibility was similar in both fresh and dried leaves whereas CP digestibility was increased by 7 units percentage and CF digestibility was decreased by 7.3 units percentage after drying. The rumen fermentation parameters were alike for both diets and their patterns were similar to those associated with known conventional diets.

It can be concluded that acacia air-drying may be used to improve its nutritive value. However, further studies on tannins aspects are needed.

\begin{tabular}{cc} 
D2 & MSE \\
\hline 53.3 & \\
30.3 & 0.50 \\
29.7 & 0.78 \\
& 0.74 \\
6.67 & \\
6.50 & 0.006 \\
77.4 & 0.73 \\
75.7 & 0.96 \\
16.9 & \\
7.9 & \\
&
\end{tabular}

